\title{
PENGARUH MEDIA ANIMASI SPARKOL VIDEOSCRIBE DALAM PEMBELAJARAN DARING TERHADAP PENGUASAAN KONSEP MAHASISWA
}

\author{
Fatimah \\ Universitas Almuslim \\ e-mail: icut.unimus88@gmail.com
}

\begin{abstract}
Abstrak
Pelaksanaan pembelajaran daring sebagai salah satu alternatif pelaksanaan pembelajaran pada masa Pandemic Covid-19 berdampak pada rendahnya penguasaan konsep mahasiswa. Rendahnya tingkat penguasaan konsep mahasiswa tersebut menyebabkan rendahnya hasil belajar mahasiswa dan secara tidak langsung menyebabkan rendahnya kualitas sumber daya manusia di bidang fisika. Untuk mengatasi permasalahan tersebut, peneliti akan menggunakan media animasi Sparkol Videoscribe dalam pembelajaran daring. Penelitian dilakukan menggunakan pendekatan kuantitatif dengan jenis penelitian eksperimen semu (quasi eksperimen). Adapun yang menjadi sampel dalam penelitian ini adalah mahasiswa Program Studi Pendidikan Fisika yang mengikuti mata kuliah fisika kuatum yang berjumlah 36 mahasiswa. Instrumen dalam penelitian ini berupa RPP, LKM dan soal tes yang diberikan melalui pre-test dan post-test. Setelah data hasil tes terkumpul, selanjutnya data dianalisis data dengan menggunakan uji $\mathrm{t}$ dengan kriteria pengujiannya adalah "Terima $\mathrm{H}_{\mathrm{o}}$ jika $\mathrm{t}_{\text {hitung }}<\mathrm{t}_{(1-\alpha)}$ dan tolak $\mathrm{H}_{\mathrm{o}}$ jika $\mathrm{t}$ mempunyai harga-harga lain pada $\mathrm{db}(\mathrm{N}-1)=35$. Berdasarkan hasil analisis tes rata-rata diperoleh bahwa $\mathrm{t}_{\text {hitung }}>\mathrm{t}_{\text {tabel }}$ yaitu 7,78 $>1,69$, maka dapat disimpulkan bahwa penguasaan konsep mahasiswa sesudah pembelajaran lebih baik sebelum pembelajaran dengan menggunakan media animasi Sparkol Videoscribe. Hal ini berarti penggunaan media animasi Sparkol Videoscribe berpengaruh terhadap penguasaan konsep mahasiswa Program Studi Pendidikan Fisika Universitas Almuslim.
\end{abstract}

Kata kunci: Media Animasi, Sparkol Videoscribe, Penguasaan Konsep

\section{THE EFFECT OF VIDEOSCRIBE SPARKOL ANIMATION MEDIA IN ONLINE LEARNING ON STUDENT CONCEPT MASTERING}

\begin{abstract}
The implementation of online learning as an alternative to implementing learning during the Covid-19 Pandemic has an impact on the low mastery of student concepts. The low level of mastery of student concepts causes low student learning outcomes and indirectly causes the low quality of human resources in the field of physics. To overcome these problems, researchers will use the animated media Sparkol Videoscribe in online learning. The research was conducted using a quantitative approach with the type of quasi-experimental research (quasi-experimental). The samples in this study were students of the Physics Education Study Program who took the quantum physics course, totaling 36 students. The instruments in this study were lesson plans, LKM, and test questions given through pre-test and post-test. After the data from the test results are collected, then the data is analyzed using the t-test with the test criteria being "Accept Ho if $t_{\text {test }}<t_{(1-\alpha)}$ and reject Ho if $t$ has other values at a degree of freedom $(N-1)=35$. Based on the results of the analysis of the average test, it was found that $t_{\text {test }}>t_{\text {table }}$, namely $7.78>1.69$, it can be concluded that students' mastery of concepts after
\end{abstract}


learning is better before learning by using the animated media Sparkol Videoscribe. This means that the use of the Sparkol Videoscribe animation media has an effect on the mastery of concepts for the students of the Physics Education Study Program, Almuslim University.

\section{Keywords: Animation Media, Sparkol Videoscribe, Concept Mastery}

\section{PENDAHULUAN}

Munculnya wabah Covid 19 di seluruh dunia berdampak pada semua aspek kehidupan termasuk bidang pendidikan. Hal ini berdampak pada pelaksanaan proses belajar mengajar di kelas yang dilaksanakan secara tatap muka (luring). Di indonesia khususnya, pada akhir bulan Maret 2020 lalu Menteri Pendidikan dan Kebudayaan Republik Indonesia mengeluarkan Surat Edaran Nomor 4 Tahun 2020 Tentang Pelaksanaan Kebijakan Pendidikan Dalam Masa Darurat Penyebaran Covid-19, yaitu aturan belajar secara daring dari rumah (Study from Home) dalam rangka pencegahan penyebaran Corona Virus Disease (Covid-19) [1]. Hal ini dilakukan untuk membatasi kontak fisik yang biasanya terjadi di lingkungan pendidikan sehingga penyebaran virus Covid-19 dapat diminimalisir. Dalam hal ini, berbagai upaya terus dilakukan oleh para pendidik untuk berinovasi dalam menjalankan pembelajaran secara daring agar perserta didik yang diajarkan dapat menyerap materi yang berikan dengan mudah.

Pelaksanaan pembelajaran daring memiliki sisi positif dan sisi negatif. Dari sisi posistif, mahasiswa yang belajar secara daring akan terbiasa belajar secara mandiri dan pembelajaran yang dijalankan lebih berpusat pada mahasiswa (Student-Centered learning). Mahasiswa dapat lebih leluasa dalam memanfaatkan berbagai sumber belajar yang ada baik dalam bentuk buku, google maupun youtube. Dari sisi negatif, mahaisiswa yang terbiasa dengan pembelajaran tatap muka dengan sistem pembelajaran yang berpusat pada guru (Teacher-Centered Learning), mereka akan merasakan kewalahan dalam menganalisis materi dan mengolahnya menjadi sebuah pengetahuan. Tentu saja hal ini dapat mempengaruhi tingkat keberhasilan mahasiswa dalam pembelajaran. Apalagi dalam perkuliahan fisika dasar, untuk memperoleh pengetahuan yang lebih riil, mahasiswa dapat melaksanakan praktikum di laboratorium untuk membangun pengetahuan fisika mereka sehingga mahasiswa lebih menguasai konsep fisika pada materi yang mereka pelajari. Dalam hal ini, perlu dilakukan kiat-kiat khusus agar pembelajaran secara daring dapat membantu mahasiswa dalam menguasi konsep-konsep fisika yang diajarkan karena tidak semua mahasiswa dapat menguasai semua konsep materi yang diajarkan. Hal ini sejalan dengan pendapat Dewi (2020) dalam penelitiannya yang bahwa tidak semua peserta didik suses dalam pembelajaran daring [1].

Pembelajaran daring merupakan aktivitas belajar yang dilakukan secara terpisah dengan internet sebangai media perantara informasi. Menurut Moore, Dickson-Deane, \& Galyen (2011), pembelajaran daring merupakan pembelajaran yang menggunakan jaringan internet dengan aksesibilitas, konektivitas, fleksibilitas, dan kemampuan untuk memunculkan berbagai jenis interaksi pembelajaran [2]. Pembelajaran dilakukan dengan memanfaatkan teknologi informasi komputer dan jaringan internet. Lebih lanjut, Fitriyani (2020) menyatakan bahwa penggunaan pembelajaran daring melibatkan unsur teknologi sebagai sarana dan jaringan internet sebagai sistem [3]. Dalam pembelajaran daring, materi dapat disampaikan secara singkron maya maupun asingkron. Secara singkron maya, pembelajaran dilaksanakan secara tatap muka dalam dunia maya dengan menggunakan berbagai fasilitas internet seperti zoom meeting, google meet, google classroom, video converence, serta berbagai aplikasi lainnya [1]. Sedangkan dengan cara asingkron dapat dilaksanakan dengan menggunakan aplikasi pembelajaran online seperti e-learning berbasis moodle, grup whatsapp dan lain-lain [4]. 
Dalam pembelajaran daring melalui elearning, dosen dapat memberikan materi pembelajaran yang dapat diakses kapan saja dan dari mana saja. Selain itu, materi yang diupload di e-learning dapat diperkaya dengan berbagai sumber belajar termasuk multimedia dengan cepat dapat diperbaharui oleh peserta didik [4]. Dengan pembelajaran daring melalui elearning, dapat menjadikan pembelajaran lebih bermakna, pendidikan lebih dari sekadar ruang kelas biasa dan tatap muka [5]. Pembelajaran melalui elearning bersifat pada pembelajaran yang berpusat pada mahasiswa yang dapat berlangsung kapan saja dan dimana saja dengan bantuan koneksi internet [6]. eLearning berarti teknik pembelajaran modern di mana pendekatan dan metode teknologi informasi digunakan untuk menyampaikan konten dan materi pembelajaran dalam berbagai bentuk baik dalam bentuk tertulis, maupun audio visual [5]. Dalam hal ini, dosen dapat memberikan konten perkuliahan dengan mengupload ke web elearning, baik dalam bentuk materi ajar, soal tugas, kuis, power point serta konten pembelajaran lainnya.

Konten perkuliahan yang diupload, terutama materi perkuliahan, harus diperhatikan dengan baik dari segi isi maupun dari segi tampilan materi tersebut karena dapat mempengaruhi kemampuan mahasiswa dalam menguasi materi. Penyampaian materi ajar melalui media yang menarik dapat memudahkan mahasiswa dalam menganalisis dan menyerap materi yang diajarkan. Penggunaan media pembelajaran dalam pembelajaran daring melalui elearning dinilai dapat mengatasi keterbatasan pada proses belajar mengajar dan dapat memfasilitasi mahasiswa dalam memahami materi [4]. Dalam hal ini, penting bagi dosen untuk mendesain dan mengambangkan media pembelajaran menjadi lebih menarik sehingga isi dari materi yang diajarkan dapat diserap oleh mahasiswa dengan baik. Media pembelajaran merupakan alat yang dapat digunakan dalam menyampaikan materi pembelajaran. Media pembelajaran dapat merangsang pikiran, perasaan, perhatian dan kemampuan atau ketrampilan peserta didik sehingga dapat mendorong terjadinya proses belajar [7].

Menurut Hamka dan Effendi, dalam pengembangan media pembelajaran perlu memperhatikan prinsip penting yang dikenal dengan istilah VISUALS, yang dapat di artikan sebagai berikut, (1) Visible (mudah dilihat), (2) Interesting (Menarik), (3) Simple (Sederhana), (4) Useful (bermanfaat), (5) Aqurate (benar), (6) Ligitimate (masuk akal), (7) Structured (tersusun dengan baik) [8]. Selain itu media pembelajaran harus memiliki syarat faktor edukasi, faktor teknik pembuatan dan faktor keindahan. Dari segi edukasi, sebuah media harus meliputi ketepatan atau kesesuaian media pembelajaran dengan tujuan atau kompetensi yang telah ditetapkan dan harus dicapai oleh peserta didik sesuai kurikulum yang berlaku. Sedangkan dari teknik pembuatan, sebuah media harus meliputi kebenaran atau konsep ilmu pengetahuan, bahan dan bentuknya kuat, tahan lama, tidak mudah. Dari segi keindahan, sebuah media harus meiliki bentuk yang elastis, ukurannya serasi dan tepat angan kombinasi warna menarik, sehingga menarik perhatian da minat peserta didik untuk menggunakannya [8] [9].

Media pembelajaran yang sering digunakan untuk memudahkan mahasiswa dalam menyerap materi perkuliahan adalah media animasi. Dalam media animasi, pembelajaran yang dilakukan dapat memberi konstribusi bagi mahasiswa untuk mengembangkan dan meningkatkan pemahaman konsep mereka [10]. Media animasi merupakan salah satu bentuk presentasi bergambar yang menarik karena merupakan simulasi dari gambar bergerak yang menggambarkan pergerakan suatu objek [11]. Animasi dapat diartikan sebagai proses perubahan bentuk atau properti suatu objek yang ditampilkan dalam kurun waktu tertentu [12]. Animasi dinilai mampu menjadi inovasi dalam pembelajaran sekolah dasar karena media animasi dapat menampilkan objek yang tidak ada secara fisik (citra) [10]. Selain itu, animasi dapat menggabungkan elemen virtual seperti teks, gambar, video, audio menjadi suatu produk yang terintegrasi. Animasi juga 
dapat menyelaraskan gaya belajar mahasiswa seperti visual, audio, kinestetik atau lainnya dan animasi memudahkan guru dalam mengembangkan aktivitas pembelajaran [12].

Dalam perkuliahan, penggunaan media animasi membuat materi yang disampaikan oleh dosen melalui e-learning menjadi lebih hidup. Materi yang diberikan dosen lebih mudah dipahami karena dalam media animasi mahsiswa tidak hanya sekedar memperoleh materi dalam bentuk teks, namun materi dapat juga diterima mahasiswa melalui gerakan visual. Adanya geerakan visual yang menarik tersebut dapat membuat mahasiswa tidak jenuh dalam memahami materi yang disampaikan dalam media tersebut. Selain itu, mahasiswa menjadi lebih responsif dalam mengikuti perkuliahan [8]. Sejalan dengan hasil penelitian tersebut, dalam penelitian ini akan dikembangkan media animasi berbasis Sparkol Videoscribe.

Sparkol videoscribe adalah salah satu aplikasi yang bisa digunakan untuk mendesain media pembelajaran berbasis video animasi berlatar putih [13]. Video Scribe Sparkol adalah software yang bisa kita gunakan dalam membuat design animasi berlatar putih dengan sangat mudah. Software ini dikembangkan pada tahun 2012 oleh Sparkol (Salah satu perusahaan yang ada di Inggris ). Video Scribe adalah cara unik untuk membuat animasi video yang menarik dengan cepat dan mudah. Anda diberdayakan untuk membawa dampak pesan anda tanpa pengetahuan, teknis, atau desain [14]. Dalam videoscribe, kita dapat mendesain media dalam bentuk video dengan konsep papan tulis yang menggunakan gambar tangan dan seolah-olah sedang menggambar atau menulis di sebuah papan. Konsep videoscribe/gambaran tangan tersebut biasa digunakan sebagai video presentasi, promosi, pembelajaran, dan lain-lain [14].

Berdasarkan permasalahan tersebut, dalam penelitian ini akan dikembangkan media animasi berbasis Sparkol Videoscribe untuk meningkatkan penguasaan konsep mahasiswa. Melalui media animasi ini diharapakan mahasiswa bisa lebih mengkonstruksi materi yang diajarkan secara mandiri dalam pembelajaran daring.

\section{METODE}

Penelitian ini menggunakan pendekatan kuantitatif, dimana pendekatan kuantitatif didasari oleh filsafat positivisme yang menekankan fenomena-fenomena objektif dan dikaji secara kuantitatif [15]. Maksimalisasi objektivitas desain penelitian ini dilakukan dengan menggunakan angka-angka, pengolahan statistik, strutur dan percobaan terkontrol.

Berdasarkan rumusan dan tujuan penelitian yang telah dirumuskan, maka jenis penelitian ini tergolong dalam penelitian eksperimen semu (quasi eksperimen). Rancangan penelitian yang dilaksanakan dapat dilihat pada Gambar 1 berikut ini.

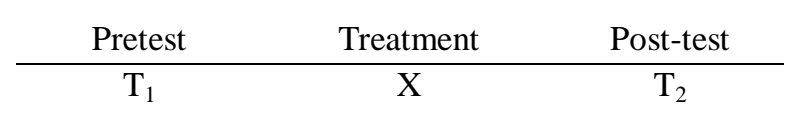

Gambar 1. Rancangan penelitian one group design

Sebelum perkuliahan dengan menggunakan media animasi Sparkol Videoscribe, mahasiswa yang menjadi subjek penelitian ini diberikan pre tes dulu untuk melihat kemampuan awal mahasiswa. Selanjutnya mahasiswa tersebut diberikan treatment atau perlakuan dalam bentuk pelaksanaan perkuliahan dengan menggunakan media animasi Sparkol Videoscribe sebanyak 4 kali pertemuan. Terakhir, mahasiswa tersebut diberikan posttest untuk melihat sejauh mana perubahan penguasaan konsep mahasiswa.

Penelitian ini dilaksanakan di Universitas Almuslim pada semester ganjil tahun 2020/2021. Adapun yang menjadi sampel dari penelitian ini adalah mahasiswa Program Studi Pendidikan Fisika yang 
mengambil mata kuliah Fisika Kuantum yang berjumlah 36 mahasiswa.

Data hasil penelitian dikumpulkan dengan menggunakan instrument lembar kerja mahasiswa (LKM) dan tes berupa tes awal (pretes) dan tes akhir (post tes). Data yang telah dikumpulkan tersebut dianalisis dengan menggunakan statistik uji $\mathrm{t}$ sebagai statistik penguji kebenaran hipotesis. Sebelum pengujian hipotesis dilakukan, terlebih dahulu dilakukan uji asumsi yaitu uji normalitas. Uji asumsi tersebut dimaksud untuk memeriksa keabsahan data apakah data yang diperoleh benar-benar terdistribusi normal.

\section{HASIL DAN DISKUSI}

Dari hasil proses belajar mengajar dengan menggunakan media animasi Sparkol Videoscribe selama penelitian, dapat dikatakan bahwa penguasaan konsep mahasiswa mengalami peningkatan yang signifikan. Hal ini terbukti dengan banyaknya soal post test yang dapat dijawab mahasiswa, sehingga ratarata hasil post tes lebih tinggi jika dibandingkan dengan rata-rata hasil pre-tes mahasiswa. Gambaran umum penguasaan konsep mahasiswa pada mata kuliah gelombang dan optik dapat dilihat pada tabel 1 berikut ini.

Tabel 1. Gambaran Umum Penguasaan konsep

\begin{tabular}{clcc}
\hline No. & \multicolumn{1}{c}{ Nilai } & Pre-Test & Post-Test \\
\hline 1. & Terendah & 20 & 40 \\
\hline 2. & Tertinggi & 67 & 93 \\
\hline 3. & Rata-Rata & 43,17 & 66,06 \\
\hline 4. & Standar deviasi & 11,13 & 14,62 \\
\hline 5. & Varians & 123,86 & 213,65 \\
\hline
\end{tabular}

Dari nilai rata-rata pre-test dan post test membuktikan bahwa adanya peningkatan penguasaan konsep mahasiswa setelah pembelajaran berlangsung dengan penggunaan media animasi Sparkol Videoscribe. Hal ini terlihat dari tingginya nilai rata-rata post-test yaitu sebesar 66,06 dibandingkan nilai ratarata pre-test yang hanya 43,17.

Peningkatan penguasaan konsep mahasiswa Program Studi Pendidikan Fisika Universitas Almuslim dianalisis dengan melalui perhitungan indeks gain ( $\mathrm{N}$-gain). Perhitungan indeks gain ini bertujuan untuk mengetahui peningkatan nilai pre-test dan post-test kelas yang diteliti. Peningkatan penguasaan konsep tersebut dapat dilihat pada Gambar 2 berikut ini.

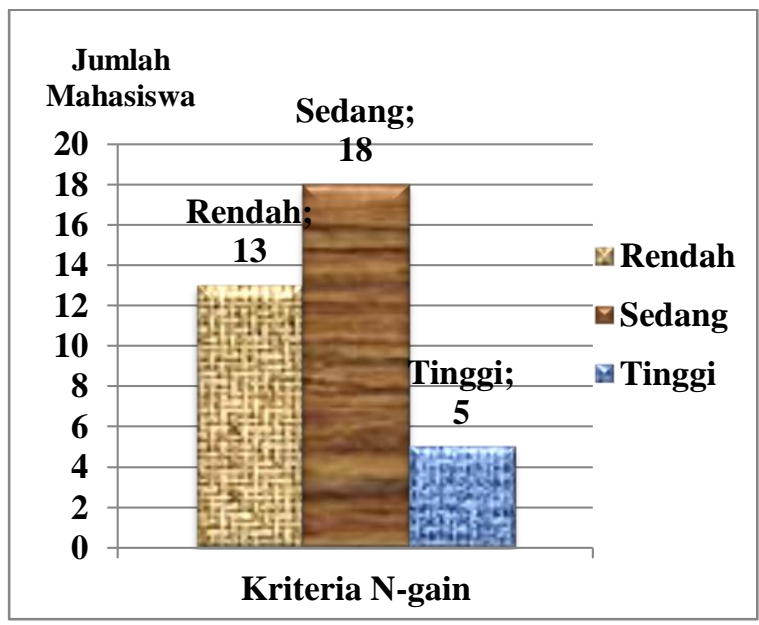

Gambar 2. Diagram Indeks Gain (N-Gain) Peningkatan Penguasaan Konsep Mahasiswa

Dari gambar 2 tersebut menunjukkan bahwa, secara umum peningkatan belajar yang dialami mahasiswa masih tergolong sedang. Hal ini ditunjukkan dengan banyaknya jumlah mahasiswa yang mengalami peningkatan belajarnya sedang yaitu mencapai 18 mahasiswa. Selanjutnya diikuti oleh mahasiswa yang peningkatan belajarnya termasuk dalam kategori rendah yaitu sebanyak 13 orang mahasiswa. Sementara mahasiswa yang mengalami peningkatan belajar yang ternasuk dalam kategori tinggi sangat sedikit yaitu hanya 5 orang mahasiswa.

Berdasarkan data yang telah diperoleh dari masing-masing tes, dapat dilakukan pengolahan data guna menjawab hipotesis 
yang telah dirumuskan, pengolahan data dilakukan dengan menggunakan statistic uji t. sebelum analisis uji $\mathrm{t}$ dilakukan, terlebih dahulu dilakukan analisis uji normalitas. Hasil analisis uji normalitas dapat dilihat pada table 2 berikut ini.

Tabel 2 Hasil Uji Normalitas Sebaran Data Pre Test dan Post Test

\begin{tabular}{ccccc}
\hline Sumber & Mean & \multicolumn{2}{c}{ Chi Kuadrat $\left(\chi^{2}\right)$} & \multirow{2}{*}{ Keterangan } \\
\cline { 3 - 4 } data & $(\overline{\boldsymbol{X}})$ & Hitung & Tabel & \\
\hline Pretest & 43,17 & 3,53 & 7,81 & Normal \\
\hline Post test & 66,06 & 3,00 & 7,81 & Normal \\
\hline
\end{tabular}

Berdasarkan tabel 2, terlihat bahwa untuk tes awal dan tes akhir diperoleh bahwa $\chi_{\text {hitung }}^{2}<\chi_{\text {tabel}}^{2}$, yang berarti bahwa kedua hasil tes tersebut terdistribusi normal.

Setelah ditentukan bahwa kedua sebaran data berdistribusi normal, selanjutnya analisis data dilanjutkan untuk menghitung tes ratarata dengan menggunakan statistik uji t. Dari perhitungan tes rata-rata, maka dapat dibuat dalam tabel hasil tes rata-rata pada tabel 4.7.

Tabel 3 Hasil Uji Tes Rata-Rata (Uji t)

\begin{tabular}{|c|c|c|c|c|c|}
\hline \multirow{2}{*}{$\begin{array}{c}\text { Jumlah } \\
\text { Gain } \\
(\Sigma \mathbf{d})\end{array}$} & \multirow[t]{2}{*}{ Md } & \multirow[t]{2}{*}{$\Sigma d^{2}$} & \multirow[t]{2}{*}{ db } & \multicolumn{2}{|c|}{$\begin{array}{c}\text { Tes Rata-Rata } \\
(\mathrm{t})\end{array}$} \\
\hline & & & & Hitung & Tabel \\
\hline 824 & 22,89 & 29736 & 35 & 7,78 & 1,69 \\
\hline
\end{tabular}

bahwa nilai jumlah gain $(\Sigma \mathrm{d})=824$. Sebelum mencari $t_{\text {hitung }}$ terlebih dahulu dicari nilai ratarata gain antara tes akhir dan tes awal (Md) sehingga diperoleh nilai $\mathrm{Md}=22,89$. Dari nilai rata-rata digunakan untuk menghitung besarnya jumlah kuadrat gain dan diperoleh jumlah kuadrat gain yaitu sebesar $\Sigma \mathrm{d}^{2}=$ 29736. Selanjutnya dilakukan perhitungan nilai $\mathrm{t}$ dan diperoleh nilai $\mathrm{t}_{\text {hitung }}=7,78$. Sedangkan nilai $t_{\text {tabel }}=1,69$ yang diperhatikan berdasarkan derajat kebebasan $(\mathrm{db})=\mathrm{N}-1$ dan taraf signifikan $\alpha=0,05$. Dengan demikian terlihat bahwa $t_{\text {hitung }}>\mathrm{t}_{\text {tabel }}$ yaitu 7,78>1,69 sehingga dapat disimpulkan bahwa hipotesis nihil $\left(\mathrm{H}_{0}\right)$ ditolak dan hipotesis kerja $\left(\mathrm{H}_{1}\right)$ diterima dengan demikian penguasaan konsep mahasiswa Program Studi Pendidikan Fisika Universitas Almuslim sesudah pembelajaran lebih baik sebelum pembelajaran dengan menggunakan media animasi Sparkol Videoscribe.

Adanya peningkatan tersebut menunjukkan bahwa penggunaan media animasi Sparkol Videoscribe dapat meningkatkan pemahaman mahasiswa terhadap konsep fisika kuantum yang diberikan dosen. Peningkatan tersebut dikarenakan dalam media animasi Sparkol Videoscribe mahasiswa, penyampaian materi oleh dosen menjadi lebih hidup dan nyata. Peningkatan penguasaan konsep tersebut juga dipengaruhi karena adanya keterlibatan mahasiswa secara aktif dalam proses pembelajaran. Selama proses pembelajaran berlangsung dengan media animasi Sparkol videoscribe, mahasiswa tidak hanya sekedar menghafal materi tetapi mahasiswa juga aktif dalam mengerjakan LKM bantuan pemahaman materi melalui media animasi Sparkol Videoscribe [14], [17]-[19]. Melalui pengalaman tersebut mahasiswa lebih mudah memahami materi yang dipelajari. Setelah mahasiswa menyelesaikan pengalaman belajarnya melalui penyelesaian LKM, dosen meminta mahasiswa untuk mempresentasikan hasil kerjanya masing-masing, kemudian hasil ini ditanggapi oleh mahasiswa yang lain. Hasil kegiatan ini memotivasi mahasiswa untuk berani menyampaikan gagasan mereka.

Secara keseluruhan rangkaian proses penelitian dengan media animasi Sparkol Videoscribe pada prinsipnya adalah membantu mahasiswa untuk meningkatkan penguasaan konsep mereka dengan cara membuat pembelajaran lebih menarik, menyenangkan dan natural. Dengan menia animasi sparkol Videoscribe dapat membuat pembelajaran yang dilakukan lebih bervariasi, tidak sematamata didominasi komunikasi verbal melalui 
penuturan kata-kata oleh dosen, sehingga mahasiswa akan termotivasi dalam belajar dan memahami materi [13], [19].

\section{SIMPULAN DAN SARAN}

\section{Simpulan}

Berdasarkan hasil analisis dan
pembahasan yang telah dikemukakan
sebelumnya diperoleh bahwa data baik pretest maupun posttest terdistribusi normal. Selanjutnya dilakukan pengujian hipotesis dan diperoleh nilai $t_{\text {hitung }}>t_{\text {tabel }}$ yaitu 7,78 $>1,69$ sehingga $t_{\text {hitung }}>t_{\text {tabel }}$, maka dapat disimpulkan bahwa penggunaan media animasi Sparkol Videoscribe dapat meningkatkan penguasaan konsep mahasiswa Program Studi Pendidikan Fisika Universitas Almuslim.

\section{Saran}

Kepada pihak lain yang tertarik pada penelitian ini, hendaknya dapat mengadakan penelitian lebih lanjut dengan indikator yang diukur tidak hanya di bidang kognitif saja, tetapi jaga diukur di bidang afektif dan psikomotorik sebagai perbandingan dari hasil penelitian ini.

\section{UCAPAN TERIMA KASIH (Jika Ada)}

Ucapan terima kasih penulis ucapkan kepada semua pihak termasuk Fakultas Keguruan dan Ilmu Pendidikan Universitas Almuslim yang telah membantu sehingga terlaksana kegiatan penelitian ini.

\section{DAFTAR PUSTAKA}

[1] W. A. F. Dewi, "Dampak COVID-19 terhadap Implementasi Pembelajaran Daring di Sekolah Dasar," EDUKATIF J. ILMU Pendidik., 2020, doi: 10.31004/edukatif.v2i1.89.

[2] A. Sadikin and A. Hamidah,
"Pembelajaran Daring di Tengah Wabah Covid-19:(Online Learning in the Middle of the Covid-19 Pandemic)," BIODIK J. Ilm. Pendidik. Biol., 2020.

[3] Y. Fitriyani, I. Fauzi, and M. Z. Sari, "MOTIVASI BELAJAR

MAHASISWA PADA

PEMBELAJARAN DARING SELAMA PANDEMIK COVID-19," Profesi Pendidik. Dasar, 2020, doi: 10.23917/ppd.v7i1.10973.

[4] F. Bakri and D. Muliyati, "PENGEMBANGAN PERANGKAT E-LEARNING UNTUK MATAKULIAH FISIKA DASAR II MENGGUNAKAN LMS CHAMILO," WaPFi (Wahana Pendidik. Fis., 2017, doi: 10.17509/wapfi.v2i1.4868.

[5] A. M. Syed, S. Ahmad, A. Alaraifi, and W. Rafi, "Identification of operational risks impeding the implementation of eLearning in higher education system," Educ. Inf. Technol., 2021, doi: 10.1007/s10639-020-10281-6.

[6] A. Bere, H. Deng, and R. Tay, "Investigating the Impact of eLearning Using LMS on the Performance of Teaching and Learning in Higher Education," 2019, doi: 10.1109/IC3e.2018.8632648.

[7] D. R. Putra and M. A. Nugroho, "PENGEMBANGAN GAME EDUKATIF BERBASIS ANDROID SEBAGAI MEDIA PEMBELAJARAN AKUNTANSI PADA MATERI JURNAL PENYESUAIAN PERUSAHAN JASA," J. Pendidik. Akunt. Indones., 2016, doi: 10.21831/jpai.v14i1.11364.

[8] D. Hamka and N. Effendi, "Pengembangan Media Pembelajaran Blended Learning Berbasis Edmodo Pada Mata Kuliah Fisika Dasar di Program Studi Pendidikan IPA," J. Nat. Sci. Integr., 2019, doi: 10.24014/jnsi.v2i1.7111.

[9] A. Asyhari and H. Silvia, "Pengembangan Media Pembelajaran Berupa Buletin dalam Bentuk Buku Saku untuk Pembelajran IPA Terpadu," 
J. Ilm. Pendidik. Fis. Al-Biruni, 2016, doi: 10.24042/jpifalbiruni.v5i1.100.

[10] R. A. Mashami and G. Gunawan, "The Influence of Sub-Microscopic Media Animation on Students' Critical Thinking Skills Based on Gender," 2018, doi: 10.1088/17426596/1108/1/012106.

[11] C. J. Daly, J. M. Bulloch, M. Ma, and D. Aidulis, "A comparison of animated versus static images in an instructional multimedia presentation," Adv. Physiol. Educ., 2016, doi: 10.1152/advan.00053.2015.

[12] Rahmatina, A. K. Kenedi, R. Eliyasni, and R. Fransyaigu, "Jigsaw using animation media for elementary school," 2019, doi: 10.1088/17426596/1424/1/012027.

[13] P. S. Wijayanti, "Pengembangan Bahan Ajar Digital Bahasa Inggris Matematika Dengan Bantuan Videoscribe Melalui E-Learning," UNION J. Ilm. Pendidik. Mat., 2018, doi: 10.30738/.v6i2.1566.

[14] C. S. Dewi, P. K. Suprapto, and L. Badriah, "Peranan Media Sparkol Videoscribe Terhadap Hasil Belajar Kognitif Siswa Lintas Minat Biologi," JPBIO (Jurnal Pendidik. Biol., 2019, doi: 10.31932/jpbio.v4i2.456.

[15] L. Sahara, N. Nafarudin, S. Fayanto, and B. A. Tairjanovna, "Analysis of Improving Students' Physics Conceptual Understanding through Discovery Learning Models Supported by Multi-representation: Measurement Topic," Indones. Rev. Phys., 2020, doi: 10.12928/irip.v3i2.3064.

[16] A. Suharsimi, "Prosedur Penelitian : Suatu Pendekatan Praktik (Edisi Revisi)," Rineka Cipta, 2010.

[17] N. K. Bengkulu, I. Sakti, Y. M. Puspasari, and E. Risdianto, "Pengaruh model pembalajaran langsung," PENGARUH Model PEMBALAJARAN LANGSUNG (Direct Instr. MELALUI MEDIA ANIMASI Berbas. MACROMEDIA FLASH TERHADAP MINAT BELAJAR DAN PEMAHAMAN KONSEP Fis. SISWA DI SMA PLUS
NEGERI 7 KOTA BENGKULU Indra, vol. X, no. 1, pp. 1-10, 2012.

[18] L. Setiawati, "Penerapan Media Animasi Sebagai Inovasi Dalam Pembelajaran Di Sekolah Dasar Ciledug 2 Kecamatan Ngamprah Kabupaten Bandung Barat," J. Penelit. Pendidik. UPI, vol. 16, no. 1, p. 124549, 2016.

[19] A. S. Pamungkas, I. Ihsanudin, N. Novaliyosi, and I. A. V. Yandari, "VIDEO PEMBELAJARAN BERBASIS SPARKOL VIDEOSCRIBE: INOVASI PADA PERKULIAHAN SEJARAH MATEMATIKA," Prima J. Pendidik. Mat., 2018, doi:

10.31000/prima.v2i2.705. 